UDC 327.8

Submitted: 22.05 .2020

LBC 66.4

Accepted: 10.07 .2020

\title{
ROLE OF STIGMATIZATION IN INTERNATIONAL PERCEPTION OF THE TRIPLE FRONTIER BETWEEN BRAZIL, ARGENTINAAND PARAGUAY
}

\author{
Irina I. Arsentyeva \\ Institute of Philosophy and Law of the Ural Branch of the Russian Academy of Sciences, \\ Yekaterinburg, Russian Federation
}

Valeriya D. Orekhova

Saratov State University, Saratov, Russian Federation

\begin{abstract}
Introduction. The article studies the Triple Frontier - a Tri-Border Area along the junction of Brazil, Argentina and Paraguay. The main aim is to analyze the reasons for its perception as an 'outlaw territory', the term generally associated with the terrorist threat. Methods and materials. Stigmatization theory, symbolic interactionism and securitization theory serve as a theoretical and methodological basis for the research. The main sources for the analysis are official reports, communiques, interviews, and publications in leading periodicals. Analysis. The article analyzes the formation of international perception of the Triple Frontier since the mid1990s. It highlights objective and subjective grounds for the negative image that has been created to date; defines the mechanisms exploited by the United States to stigmatize the region and the reasons for selective securitization of threats emanating from there. According to the authors, the Triple Frontier is characterized by a complex set of relationships between multiple stakeholders. Their diverse and often contradictory interests form a convergent-divergent space which affects security of local residents, security of Latin American countries, and, to a certain extent, international security in general. Results. In the final part of the article the main scientific results obtained during the research are formulated, and possible ways of further development regarding this case are outlined. The authors conclude that to destigmatize the Triple Frontier it is necessary to rebrand it - to create a new, positive image, taking advantage of the geopolitical and geo-economic situation, as well as the availability of unique water resources.

Key words: the Triple Frontier, stigmatization theory, symbolic interactionism, securitization, security, security threats, 'outlaw territory', terrorism.

Citation. Arsentyeva I.I., Orekhova V.D. Role of Stigmatization in International Perception of the Triple Frontier Between Brazil, Argentina and Paraguay. Vestnik Volgogradskogo gosudarstvennogo universiteta. Seriya 4. Istoriya. Regionovedenie. Mezhdunarodnye otnosheniya [Science Journal of Volgograd State University. History. Area Studies. International Relations], 2021, vol. 26, no. 4, pp. 173-182. DOI: https://doi.org/10.15688/jvolsu4.2021.4.15
\end{abstract}

УДК 327.8

Дата поступления статьи: 22.05.2020

$\overrightarrow{\widetilde{\top}}$ ББК 66.4

Дата принятия статьи: 10.07 .2020

\section{РОЛЬ СТИГМАТИЗАЦИИ В МЕЖДУНАРОДНОМ ВОСПРИЯТИИ ТРОЙНОЙ ГРАНИЦЫ БРАЗИЛИИ, АРГЕНТИНЫ И ПАРАГВАЯ}

\author{
Ирина Ильинична Арсентьева \\ Институт философии и права Уральского отделения РАН, \\ г. Екатеринбург, Российская Федерация
}

\section{Валерия Дмитриевна Орехова}

Саратовский национальный исследовательский государственный университет им. Н.Г. Чернышевского,

г. Саратов, Российская Федерация 


\section{МЕЖДУНАРОДНЫЕ ОТНОШЕНИЯ В ПРОШЛОМ И НАСТОЯЩЕМ}

Аннотация. Введение. Объектом исследования в статье выступает Тройная граница - трехсторонняя пограничная область на стыке Бразилии, Аргентины и Парагвая. Основной целью является анализ причин ее международного восприятия как «территории вне закона», чье наименование ассоциируется с террористической угрозой. Meтоды u материалы. Теория стигматизации, символический интеракционизм и теория секьюритизации образуют теоретико-методологическую базу исследования. Источниками служат официальные доклады, коммюнике, интервью, публикации в ведущих периодических изданиях. Анализ. В статье анализируется процесс формирования международного восприятия Тройной границы с середины 1990-х гг.; выделяются объективные и субъективные основания негативного образа, который создан на сегодняшний день; определяются механизмы, использованные Соединенными Штатами Америки для стигматизации региона, и причины выборочной секьюритизации исходящих оттуда угроз. По мнению авторов, Тройная граница характеризуется сложным комплексом взаимоотношений множества стейкхолдеров. Их разнообразные и зачастую контрадикторные интересы формируют конвергентно-дивергентное пространство, влияющее на безопасность местных жителей, безопасность латиноамериканских стран и, в определенной степени, на международную безопасность в целом. Результатыл. В заключительной части статьи формулируются основные научные результаты, полученные в ходе исследования, намечаются возможные пути дальнейшего развития ситуации. Авторы приходят к выводу, что для дестигматизации Тройной границы необходимо провести ее ребрендинг - создать новый, положительный имидж, воспользовавшись преимуществами геополитического и геоэкономического положения, а также наличием уникальных водных ресурсов. Вклад авторов. И.И. Арсентьевой выстроена общая концепция исследования, осуществлена научная редакция статьи, проанализированы иностранные источники и исследования, которые использовались при написании аналитической части работы. В.Д. Ореховой изучены работы англоязычных авторов, на которых базируется теоретико-методологическая часть исследования.

Ключевые слова: Тройная граница, теория стигматизации, символический интеракционизм, секьюритизация, безопасность, угрозы безопасности, «территория вне закона», терроризм.

Цитирование. Арсентьева И. И., Орехова В. Д. Роль стигматизации в международном восприятии Тройной границы Бразилии, Аргентины и Парагвая // Вестник Волгоградского государственного университета. Серия 4, История. Регионоведение. Международные отношения. - 2021. - Т. 26, № 4. - С. 173-182. (На англ. яз.). - DOI: https://doi.org/10.15688/jvolsu4.2021.4.15

Introduction. Almost in the center of the Southern Common Market (hereinafter MERCOSUR) the state borders of Brazil, Argentina and Paraguay converge, forming the so-called Triple Frontier or Tri-Border Area (Spanish: la Triple Frontera). Since the mid-1990s, this zone has been the focus of attention of the United States, which claims it to be an 'outlaw territory' featured in terrorism, smuggling and corruption. One of our previous papers has already investigated this topic, but the issue of terrorism has not been considered. In our opinion, it requires a separate analysis, including theoretical and methodological one.

Particular interest in the terrorism issue is due to the fact that the very name 'the Triple Frontier' started being used in the international lexicon after the US intelligence services had suspected the presence of Islamist terrorist groups in the region. This collocation appeared after two terrorist attacks in Buenos Aires in 1992 and 1994, at first in the discourse of public officials and in the US periodicals, and then on the pages of Latin American newspapers and in Spanish-language documents. It finally came in use in 1998, when Brazil, Argentina and Paraguay signed the General Plan for the Tri-Border Area (Spanish: el Plan General de Seguridad para la Triple Frontera), which gave a prominent place to preventive counter-terrorism measures.

Thus, the terrorist threat has become some kind of an essential attribute for the name of the region, so the phrase 'the Triple Frontier' has strong negative connotations, which make up a sort of a label or 'stigma'. In turn, the latter notion is related to the stigmatization theory and, in a broader sense, to symbolic interactionism (in the framework of this study, stigma (Greek: $\sigma \tau i ́ \gamma \mu \alpha$ - 'mark / spot'), will be interpreted as a verbal label capturing a negative trait or phenomenon, and stigmatization as the process of purposeful use of such labels towards individual actors).

Therefore, we consider it possible to use these theoretical and methodological bases to analyze the reasons for the international perception of the Triple Frontier as an 'outlaw territory' associated with terrorism. This analysis 
is the main aim of the study and it presumes consistent accomplishment of the following objectives:

- to identify those provisions of symbolic interactionism and the stigmatization theory that can be rewarding in the analysis of the chosen issue;

- to describe as a process how introduction of stigmas into political discourse and their subsequent securitization occurs;

- to analyze how international perception of the Triple Frontier is being formed by means of highlighting objective and subjective grounds for the negative image that has been formed to date;

- to assess the relevance of the terrorist threat to security of residents living in the TriBorder Area, national security of Latin American states and international security in general;

- to draw main conclusions obtained in the course of the study, and to outline possible ways for further development of the situation.

It should be noted that despite sufficient popularity of the Tri-Border Area at the international level, Russian researchers practically do not address this topic. In addition, it cannot be denied that there have been repeated attempts to make Russian foreign policy an object of stigmatization in recent years, so the analysis of how this process takes place is doubtlessly of interest. These circumstances determine relevance, scientific and practical significance of this study.

Methods and materials. The stigmatization theory emerged on the basis of symbolic interactionism, the main provisions of which were developed by representatives of the Chicago School of Sociology, G. Mead [16] and H. Blumer [3]. The central concept is symbolic interpretation of interpersonal interaction. In the process of communication people first try to understand the intentions of others, to determine their meaning in accordance with their own mentality and, based on the reached conclusions, construct responses through language, gestures, cultural symbols, etc. In other words, the reaction is based not on the actions of other people, but on the importance attached to these actions. We will proceed from this position when analyzing the processes of stigmatization in international relations.

A. Wendt, the developer of constructivism in the theory of international relations, synthesized a lot of achievements of sociology, including symbolic interactionism. The researcher focused on the processes of interaction between the actors (agents) that create social reality. Any social structure, as well as world politics and international relations, are primarily considered by him, first of all, not as a material, but as an intersubjective entity. "The character of international life is determined by the beliefs and expectations that states have about each other, and these are constituted largely by social rather than material structures" [24, p. 20].

The approach suggested by A. Wendt has gained popularity among researchers developing the problems of identity and deviant behavior of individual actors, since it gives an opportunity to take a new look at the mechanism of norm formation in world politics as a result of a competition between different ideas of states concerning what is right and appropriate (see: [1]).

Another well-known representative of the Chicago School of Sociology, E. Goffman, compared interaction between people with the theater, where everyone performs a number of roles and, adjusting to circumstances, constructs different scenarios of behavior. In case someone's actions do not conform to existing, generally accepted standards, the processes of his / her social rejection are triggered.

It is important for our research, that E. Goffman was one of the first who started using the concept of 'stigma' [11] - the attribute, distinctive feature, the presence of which allows us to qualify a person's belonging to a certain discrete social category. In turn, it is discriminated by 'normal' majority - people who do not have this characteristic. Symbols with different degrees of transparency might become a basis for stigmatization, some of them are so poorly expressed that they can be easily hidden from others, i.e., social information plays a key role in whether a person can avoid being 'stigmatized'.

It is obvious that stigmatization might occur not only at the level of interpersonal interactions, but also in international relations (in this regard, it is possible to recall the famous thesis of A. Wendt "States are people too" [24, p. 215]). The researchers working in this field identify stages of stigmatization [15]. Firstly, the condemned by the society attributes of a specific object are identified. Then a simplified image (stamp) clothed in the appropriate language form is created on 
their basis, designing a stigma, which starts functioning as a negative (intolerant) variation of the 'we-others' opposition. If the one who created the stigma has influence on the world stage, then stigmatization changes the position of the 'stigmatized' in the system of international relations and leads to its structural discrimination fixed at the normative level.

'State sponsors of terrorism', 'rogue states'/ 'pariah states', 'backlash states' and 'failed states', as well as 'outlaw territories' / 'lawless territories' considered in this article are examples of stigmas used in world politics and international relations. Almost all of them are the products of the US political culture and were actively exploited in the political discourse of the early 2000s, when the global war on terrorism became the defining trajectory of the American foreign policy strategy.

Let's examine 'outlaw territories' in more detail. In general terms, researchers define them as areas governed by transnational criminal, terrorist and insurgent organizations which are engaged in illegal economic activities out of effective state control. "It is a dream come true for criminals and terrorists to find a place where no one can look for them, and where they can mix with, ally with... and work with minimum interference from legal authority" $[14$, p. 392]. Geographical areas that meet these requirements are connected to each other in the same way as international corporations arranging production cycles in different countries within a single financial and logistics network. Having considered 80 examples of such territories (including the Triple Frontier), American researchers S. Brown and M. Hermann have called them 'black spots' in the system of international relations like black holes in astronomy [5].

It is also important for us to trace back how stigmas are introduced into political discourse. In this case discourse refers to a series of interrelated statements in a certain context, at certain time, in a certain place, and structuring reality in a certain way [13, p. 223]. At the same time, it should be taken into account that by using particular language means while naming a phenomenon we interpret its essence and express our attitude to it. In the political sphere the phenomenon might not only be interpreted, but also designated as a threat to national and/or international security.

Securitization theory developed by the Copenhagen School is of interest in this regard, as it defines security discourse formation [6]. In general, the mechanism is the following: a certain object at a certain point of time starts being securitized - interpreted as a source of threat, and the securitizing actor seeks to convince public of its rightness. This happens through a special (perlocutionary) speech act, which declares the threat, demands close attention to it, and requests the use of extraordinary measures to neutralize the source of danger. The securitization process is considered complete when the speech act reaches its goal by finding of political elite and population, mass media and academic community. The probability of such development depends on a number of domestic and foreign policy conditions, i.e. on the political context, as well as on reality of the alleged danger, which seems absolutely logical at first glance.

However, in practice, the issue about the extent to which stigma reflects reality, the stigmatized and subsequently securitized objects really pose a threat, is debatable. Thus, H. Müller, former Director of Peace Research Institute Frankfurt, argues that we are able just to analyze discourse, without having any hope to discover real things behind the words [18, p. 382]. Based on this, it is possible to assume that often the formed stigmas are some kind of simulacra that generate the second-order reality, and can be used for substitution of concepts in the course of achieving certain political goals. For instance, organized crime refers to domestic problems, but by appealing to its connection with the terrorist threat it is easier to justify interference in the internal affairs of sovereign states.

At the same time, it is obvious that labels giving negative interpretation of events taking place in some states and regions affect their perception by the international community. In this regard the point of view of the American researcher M. Clary, who uses the concept of 'national reputation' [7], is of interest. He believes it is constructed on an intersubjective level under the influence of lots of factors and to a certain extent is a subject of manipulation. Reputation reflects behavior, rhetoric, intentions, interests, and goals of a country on the international arena. Compared to actions committed in the past it is expressed in dynamics, so its formation is continuous. Consequently, the stigma only captures a certain historical context. However, 
once fixed in discourse, it continues to influence national reputation even after its disappearance. According to M. Clary, neutralization of a stigma is possible as a result of expensive rebranding, which means not only rejection of deviant behavior, but also pinning occurred reassessment in corresponding actions. In other words, it is not enough to take criticism from the international community into account, it is essential to counter it with something new that gives a chance to create and consolidate a positive image. In the framework of our research this process can be provisionally designated as destigmatization.

The stated above theoretical and methodological grounds allow us to look at the object of the research - the Triple Frontier - from an unusual perspective when analyzing formation of its international perception since the mid-1990s and describing the role of the United States in this process. The following sources are used to ensure reliability of the analytical part of the study: reports of the State Department and the Library of Congress, Communique of the $3+1$ Group (Argentina, Brazil, Paraguay, and the United States), interviews with officials, publications in leading US periodicals, and others.

Analysis. The Triple Frontier of Brazil, Argentina and Paraguay is located at the convergence of two powerful rivers - the Parana River and one of its largest tributaries, the Iguazu River. The territory includes three cities: Brazilian Foz do Iguaçu, Argentine Puerto Iguazu and Paraguayan Ciudad del Este. They are sometimes referred to as the 'triple city' or 'triangle' because in fact they constitute a conurbation, within its borders residents move freely using two international border bridges and a ferry crossing. In addition, the location on the rivers provides numerous, almost uncontrolled entry and exit points.

The main geo-economic advantage of the Triple Frontier is its intermodal nature linking a number of international trade chains. Due to the existing infrastructure (three airports, developed road and banking networks), this zone is an excellent gateway to major South American markets with high purchasing power.

The Binational (Brazilian-Paraguayan) hydroelectric power station, the Itaipu Dam, one of the two largest in the world along with the Chinese Sanxia (the Three Gorges Dam), has a significant impact on the development of the Tri-
Border Area. Moreover, it is geographically located at the epicenter of the Guarani Aquifer, one of the largest and easiest aquifers on the planet in terms of access.

At the same time, it is a territory where poverty and unemployment flourish; it is characterized by an ultra-high level of shadow economy and corruption being a real logistics 'paradise' for traffic in drugs, weapons, counterfeit products, illegal migration, forged documents trading, etc. Beyond that, a lot of experts, primarily Americans, argue that there is a threat of growing radical Islamist sentiment in the Tri-Border Area, where a large number of people from Arab countries live. It is the latter aspect that we will focus on in more detail.

The notion 'Triple Frontier' entered the international political discourse after two terrorist attacks in Buenos Aires - on the Israeli Embassy (1992) and the Argentine Israelite Mutual Association (1994). As a result of the explosion of powerful bombs, 114 people were killed and more than 500 were injured. The US intelligence agencies claimed the attacks were organized by Syrian-Lebanese merchants living in the TriBorder Area, who, being involved in the trade of weapons and drugs, were preparing a springboard for Hezbollah (it should be remarked that in those days none of the Latin American countries included it in the list of terrorist organizations).

The collapse of the World Trade Center's Twin Towers in New York (2001) reinforced these suspicions. The pressure on the governments of Argentina, Brazil, and especially Paraguay was increased in order to get them control the problem area. According to Washington, Middle Eastern islamists (primarily from Iran and Lebanon) can get financial support from numerous trading companies located in the Tri-Border Area and owned by the Arabs, use established channels for money laundering and documents forgery in order to enter the giant Amazon basin, whose inaccessibility provides favorable conditions for terrorist camps deployment.

It should be noted that the Tri-Border Area is home to one of the largest Arab communities in South America which, according to various estimates, counts from 20 to 30 thousand people (while the total population in the 'triangle' is about 600 thousand); mostly they are Lebanese, who control some key directions of cross-border trade. 
According to the US intelligence agencies, many of them may be members of sleeper cells of international terrorism, which are ready to be activated at any time on the orders of their centers.

The Triple Frontier began to appear in the US State Department's reports, Patterns of Global Terrorism in 2000. At first, there were three paragraphs, which characterized the Tri-Border Area as a focal point for Islamic extremism in Latin America, although the authors recognized that no acts of international terrorism were committed in any of the three countries during the year [19]. After 9/11 Washington included the issue of the Triple Frontier in the strategy to combat international terrorism. In Patterns of Global Terrorism 2001, the State Department devoted 11 paragraphs to the Triple Frontier, having defined it as a hub for Hezbollah and HAMAS, used for financial and logistical purposes [20]. In 2003 this was also stated in one of the interviews given by General J. Hill, who headed the US Southern Command at the time. According to him, Middle Eastern Islamist groups annually received from 300 to 500 million dollars from the 'triangle' and similar areas of Latin America [23].

Among the published works it is worth noting the report Terrorist and Organized Crime Groups in the Tri-Border Area (TBA) of South America [12], prepared by the Federal Research Division, the Library of Congress, in 2003. Although the preface to the report acknowledged that it was based on open sources (mainly periodicals), the text itself categorically stated Islamist terrorist groups used the Triple Frontier to raise funds, recruit, and organize attacks in the Americas.

The American establishment has constantly stressed inability of Brazil, Argentina and Paraguay to control the situation; such poor governance creates threats to international security and requires an immediate response. Thus, in 2003, President G.W. Bush demanded from Brazil to send troops to Iraq and strengthen control over the Triple Frontier [4], which once again proved that the object of securitization was a terrorist threat.

After the statements of US officials, the attention of the American media to the Tri-Border Area has increased: if in the 1990s they addressed this topic sporadically, since 2001 it has happened regularly. As evidence, the study The Triple Frontier: Globalization and Social Construction of the Space (Spanish: La Triple Frontera: Globalización y construcción social del espacio) might be used [17]. Its authors, S. Montenegro and V. Gimenez, analyzed publications in such leading American newspapers as The Washington Post, The Washington Times, and The New York Times. In the end they came to the conclusion that since the mid-1990s perception of the Triple Frontier was expressed in a similar matrix of discourses: 'outlaw land', a remote and 'strange' region; and the three countries whose jurisdiction it was could not or did not want to establish any order there [17, p. 47].

After the events of September 11, The Washington Times wrote that the Triple Frontier, being highly sensitive to corruption and shadow economy, may be a convenient place for planning and financing terrorist activities. The same newspaper, with reference to experts from the Terrorism Research Center (Virginia, USA), also claimed that the Tri-Border Area was a training zone for killing Americans and Jews [17, p. 51]. The content of articles in The New York Times and The Washington Post was also fully complied with the assessments of the US State Department. One of the most important aspects was to emphasize weak potential of local authorities in managing the region, which is almost an independent 'gray zone', 'space without a state', where mafia structures operate freely and with impunity [17, p. 62].

So, it is clear that the stigma 'outlaw territory' used by the American establishment towards the Triple Frontier in the context of the fight against terrorism has entered the agenda of journalism and academic community. This has led to a corresponding attitude of the population and, given the level of influence and popularity of the American media, has formed international perception of the Triple Frontier. Latin American periodicals have also been influenced by the American approach, although, of course, it is characterized by a greater variability of estimates.

The authorities of Brazil, Paraguay and Argentina, for their part, claimed they had found no solid proof that a network for financing terrorism in the 'triangle' existed. However, after the terrorist attacks in Buenos Aires, the Triple Frontier has become more strictly controlled; border monitoring and surveillance of people crossing it, the Arab Diaspora representatives and 
foreign citizens, have been enhanced. In 1996, the Tripartite Command of the Triple Frontier, an anti-terrorist unit of the three countries' police forces, was formed.

In 2002, based on the Tripartite Command, the 3+1 Group with the participation of the United States was created. It was assumed that the cooperation would cover a number of areas, including anti-terrorist measures and investigation of cross-border crimes. The emphasis was on preventive activities. In the first years of its work information exchange on possible terrorist attacks in the Tri-Border Area was intensified, measures for its joint patrolling were developed [8], and in the framework of MERCOSUR the information system about those entering its territory was designed, similar to the one which is shared by the states of the Schengen zone. A number of Arab citizens suspected of links to radical Islamist groups were extradited from the Tri-Border Area.

However, eventually the cooperation has almost stopped. This was largely due to Brazil's resistance to the presence of American intelligence within the Triple Frontier. In recent years, Argentina and Paraguay have shown their intention to resume the work of the group [22] including the recognition of Hezbollah as a terrorist organization in 2019 [10]. But full cooperation, which, in our opinion, could contribute to solving some acute problems of the 'triangle', is impeded both by the low level of economic development, complicating a consistent fight against negative phenomena in the Latin American countries and the emphasized military focus on counterterrorism, promoted by Washington in bilateral relations and within the inter-American system.

It should be noted that American statements concerning the terrorist threat in the Tri-Border Area are constantly criticized for the weak evidence base. In 2019, the journal NACLA Report on the Americas published an article with the catchy title Tales of Terror on the Triple Frontier [4]. Its author, F. Brancoli, a professor at the Federal University of Rio de Janeiro, believes that the issue of terrorism there is the result of longtime US selective securitization of threats emanating from the region.

In this regard it is logical to wonder: why was the terrorist threat chosen as the securitization object? The charges of organized crime would have been much more convincing. The Tri-Border
Area, called the 'attraction pole of illegal activities' [2], is a classic example of the 'black spots' that we have mentioned in the section Methods. And it is obvious that the current situation is not just an implication of a high level of corruption, but its institutionalization, which means transition from the category of crimes of individual officials to a mass social phenomenon, common practice, a usual element of the socio-economic system. "In fact, political power gives organized crime recognition in society and allows it to acquire legitimacy" [21, p. 120].

The Triple Frontier in its current state is a convergent-divergent space of relationships between a lot of stakeholders who seek to obtain financial profit, and weak government regulation leads to the situation when the gray and black markets are the main engines of economic activity. In this connection, let us return to the question why the label 'outlaw territory' was linked not to organized crime, smuggling and corruption, but to international terrorism. In our opinion, the answer is quite clear. In the first case, this remains an internal problem of Brazil, Argentina and Paraguay, falling, for example, under the jurisdiction of the International Criminal Police Organization (INTERPOL); in the second scenario, it gives Washington greater opportunities to act in accordance with its own ideas about the proper world order and the national mission in its establishment.

The US interest in the region is quite understandable: the processes taking place there (like drug trafficking or arms smuggling) pose threats to its national security. However, geopolitical factors cannot be discarded. Thus, control of the Tri-Border Area would give the United States additional leverage over MERCOSUR, which accounts for more than half of the population and GDP of the Latin American region. In addition, as already noted, the considered territory is located the epicenter of the Guarani Aquifer. It is the Guarani, with its fresh water reserves estimated at 37 thousand cubic kilometers, that has been recognized as the most valuable strategic asset of the region, which is especially important today, when global water wars are becoming more and more real.

In conclusion, it should be stated that this study does not aim to track how the perception of the U.S. Triple Frontier was changed depending 
on which political party - Republicans or Democrats - was governing. At the same time, it is obvious that the greatest activity on the part of the United States was observed in the early 2000s during the presidency of Republican G.W. Bush due to the declared fight against terrorism in all directions. After B. Obama came to power, the name 'Triple Frontier' was quite rarely used in the American political discourse, and this trend continues to this day. Thus, the State Department's Country Reports on Terrorism 2018 [9] gives it a minor place, traditionally referring to the established tradition, to financing of Hezbollah. However, in our view, the problem is not how the American assessment of the situation in the Tri-Border Area has been changing, but the fact that it is extremely difficult to get rid of labels once attached; moreover, they are easily 'revived' at the slightest change in the political context. Therefore, a lot depends on the further actions of Brazil, Argentina and Paraguay. In this case, as already noted, we can argue about the need for rebranding or destigmatization, but we must understand that this is a long and expensive process in every respect.

Results. The aim of the work was to analyze the international perception of the Triple Frontier held by Brazil, Argentina and Paraguay in the course of the stigmatization theory and to find out the reasons why this territory is associated primarily with the terrorist threat. Based on the results of the research, the following scientific outcome was obtained:

- the provisions of symbolic interactionism and the stigmatization theoryhave been highlighted, it allows us to explain differences in assessments of a degree and nature of the threat posed by the Triple Frontier to international security;

- the article identified the mechanisms used by the United States of America to stigmatize the Triple Frontier as an 'outlaw territory' and selectively securitize threats emanating from it, so that the Tri-Border Area has gained an international reputation as a financial and logistics hub for Islamic extremism;

- the objective reasons for the negative image of the Triple Frontier have been defined, which give grounds for experts to attribute it to 'black spots' in the regional security system.

The results suggest that Brazil, Argentina and Paraguay should first restore control over the Triple Frontier, where criminal organizations and individuals are currently engaged in illegal economy almost with impunity. In this case, state control is understood as suppression of any such activity, which requires a comprehensive, consistent counteraction to corruption in local government bodies, as well as development of more effective border control measures aimed, among others, at preventing smuggling of goods re-exported from Paraguay (certain steps are already being taken by the Brazilian side).

It is also necessary to rebrand this territory - to create a new, positive international image, taking advantage of the position in the center of MERCOSUR and the Guarani Aquifer, which potentially opens great opportunities for socio-economic development. An additional significant advantage is that there are the Iguazu Falls included in the UNESCO World Heritage List - one of the most attractive places on the planet from the tourist perspective. However, the most promising, in our opinion, is the socio-ecological direction associated with the comprehensive study and conservation of unique water resources. This particular area implies excellent opportunities for expanding cooperation with other actors in international relations and gradually improving the image of the Triple Frontier. Some projects are already being developed, such as the Project for Environmental Protection and Sustainable Development of the Guarani Aquifer System, implemented by Brazil, Argentina, Paraguay, and Uruguay with the support of the Global Environment Facility, the World Bank, several other international organizations and individual states.

To date, the Triple Frontier does not belong to territories with a high risk of terrorist attacks. However, radicalism is winning in areas prone to clientelism where illegal activities thrive against the backdrop of institutional corruption; organized crime is localized, and the majority of the population is below the poverty line, unable to earn a living legally. Therefore, on the one hand, a consistent practical fight against these negative phenomena is needed, on the other - in-depth scientific research that will identify the main security threats and develop mechanisms to neutralize them without labeling is essential. 


\section{REFERENCES}

1. Adler-Nissen R. The Social Self in International Relations: Identity, Power and the Symbolic Interactionist Roots of Constructivism. ERIS European Review of International Studies, 2016, vol. 3, pp. 27-39. DOI: https://doi.org/10.3224/eris.v3i3.27340.

2. Bello Arellano D. La Triple Frontera como polo de atracción de actividades ilícitas: Condiciones endógenas institucionales e ilegalidad. Atenea, (Concepción), 2013, no. 508. DOI: https://doi.org/ 10.4067/s0718-04622013000200008.

3. Blumer H. Symbolic Interactionism: Perspective and Method. Berkeley, University of California Press, 1986. 208 p.

4. Brancoli F. Tales of Terror on the Triple Frontier. NACLA Report on the Americas, 2019, vol. 51, no. 1 , pp. $85-89$. DOI: https://doi.org/10.1080/ 10714839.2019.1593697.

5. Brown S.S., Hermann M.G. Transnational Crime and Black Spots: Rethinking Sovereignty and the Global Economy. London, Palgrave Macmillan, 2020.250 p.

6. Buzan B., Waever O., de Wilde J. Security: A New Framework for Analysis. Boulder, Lynne Rienner Publishers, 1998. 239 p.

7. Clary M.Q. From Pariah to Phoenix: Improving a National Reputation from the Ashes of the Past. Lanham, Lexington Books, 2020.210 p.

8. Communique of the $3+1$ Group on TriBorder Area Security, Washington, DC. URL: https:// 2009-2017.state.gov/p/wha/rls/70992.htm (accessed 6 January 2020).

9. Country Reports on Terrorism 2018, U.S. Department of State. URL: https://www.state.gov/wpcontent/uploads/2019/11/Country-Reports-onTerrorism-2018-FINAL.pdf(accessed 10 March 2020).

10. Fighting Terror in the Tri-Border Area $(Q \& A$ with Alison August Treppel, Executive Secretary of the Organization of American States's Inter-American Committee Against Terrorism). URL: https:// www.wilsoncenter.org/article/fighting-terror-the-triborder-area (accessed 5 February 2020).

11. Goffman E. Stigma: Notes on the Management of Spoiled Identity. New Jersey, Prentice-Hall, 1963. 147 p.

12. Hudson R. Terrorist and Organized Crime Groups in the Tri-Border Area (TBA) of South
America. URL: https://www.loc.gov/rr/frd/pdf-files/ TerrOrgCrime_TBA.pdf(accessed 22 December 2019).

13. Lazar A., Lazar M.M. The Discourse of the New World Order: "Out-Casting" the Double Face of Threat. Discourse \& Society, 2004, vol. 15, no. 2-3, pp. 223-242. DOI: https://doi.org/10.1177/0957926504041018.

14. Levitsky M. Dealing with Black Spots of Crime and Terror: Conclusions and Recommendations. International Studies Review, 2008, vol. 10, pp. 392-395.

15. Link B.G., Phelan J.C. Conceptualizing Stigma. Annual Review of Sociology, 2001, vol. 27, pp. 363-385.

16. Mead G.H. Mind, Self, and Society: From the Standpoint of a Social Behaviorist. Chicago, University of Chicago Press, 1934. $400 \mathrm{p}$.

17. Montenegro S., Gimenez Beliveau V. La Triple Frontera: Globalización y construcción social del espacio. Buenos Aires, Miño y Dávila editores, 2006. $256 \mathrm{p}$.

18. Muller H. Security Cooperation. Handbook of International Relations. London, Sage, 2002, pp. 369-392.

19. Patterns of Global Terrorism 2000. U.S. Department of State. URL: https://20092017.state.gov/j/ct/rls/crt/2000//index.htm (accessed 6 December 2019).

20. Patterns of Global Terrorism 2001. U.S. Department of State. URL: https://20092017.state.gov/j/ct/rls/crt/2001/pdf/index.htm (accessed 15 December 2019).

21. Pérez Calderón J. La Triple Frontera como centro de atracción del yihadismo en América Latina: Orientación teórico-histórica. Hallazgos, 2018, vol. 14, no. 27, pp. 111-128. DOI: https://doi.org/10.15332/ s1794-3841.2017.0027.05.

22. Triple Frontera: Argentina busca reeditar la cooperación con Brasil, Paraguay y los Estados Unidos. URL: https://www.clarin.com/politica/triplefrontera-argentina-busca-reeditar-cooperacion-brasilparaguay-unidos_0_ESefhQQ1Z.html (accessed 28 January 2020).

23. U.S. General: Islamic Rebels Get Cash from Latin America Gangs. URL: https:// www.orlandosentinel.com/news/os-xpm-2003-03-100303100117-story.html (accessed 4 February 2020).

24. Wendt A. Social Theory of International Politics. Cambridge, Cambridge University Press, 1999. 432 p. 


\section{МЕЖДУНАРОДНЫЕ ОТНОШЕНИЯ В ПРОШЛОМ И НАСТОЯЩЕМ}

\section{Information About the Authors}

Irina I. Arsentyeva, Doctor of Sciences (Politics), Associate Professor, Leading Researcher, Institute of Philosophy and Law of the Ural Branch of the Russian Academy of Sciences, Sofyi Kovalevskoy St, 16, 620108 Yekaterinburg, Russian Federation, airen1@yandex.ru, https://orcid.org/0000-0003-4145-8790

Valeriya D. Orekhova, Candidate of Sciences (Politics), Assistant, Department of International Relations and Russian Foreign Policy, Saratov State University, Astrakhanskaya St, 83, 410012 Saratov, Russian Federation, valeriaorekhova@gmail.com, https:/orcid.org/0000-0002-1381-608X

\section{Информация об авторах}

Ирина Ильинична Арсентьева, доктор политических наук, доцент, ведущий научный сотрудник, Институт философии и права Уральского отделения РАН, ул. Софьи Ковалевской, 16, 620108 г. Екатеринбург, Российская Федерация, airen1@yandex.ru, https://orcid.org/0000-0003-4145-8790

Валерия Дмитриевна Орехова, кандидат политических наук, ассистент кафедры международных отношений и внешней политики России, Саратовский национальный исследовательский государственный университет им. Н.Г. Чернышевского, ул. Астраханская, 83, 410012 г. Саратов, Российская Федерация, valeriaorekhova@gmail.com, https://orcid.org/0000-0002-1381-608X 